\title{
PENERAPAN PENDIDIKAN KARAKTER DALAM PEMBELAJARAN BAHASA INGGRIS DI SDN 106160 DESA TANJUNG REJO KECAMATAN PERCUT SEI TUAN
}

\author{
Yugi Diraga Prawiyata \\ Universitas Muslim Nusantara (UMN) Al-Washliyah \\ Jl. Garu II No. 93 Medan \\ Pendidikan Bahasa Inggris \\ yugidiragaprawiyata@gmail.com
}

\begin{abstract}
Abstrak
Tulisan ini memaparkan penerapan pendididikan karakter dalam pembelajaran bahasa Inggris. Pendidikan karakter ialah segala sesuatu yang dilakukan guru, yang mampu mempengaruhi karakter peserta didik. Guru membantu membentuk watak peserta didik. Hal ini mencakup keteladanan bagaimana perilaku guru, cara guru berbicara atau menyampaikan materi, bagaimana guru bertoleransi, dan berbagai hal terkait lainnya. Secara umum, paparan nilainilai utama karakter selanjutnya dapat dicerminkan, antara lain pada saat memformulasikan indikator dan mengembangkan bahan ajar. Berikut ini adalah beberapa contoh pengintegrasian masing-masing nilai karakter pada indikator dan bahan ajar dalam pembelajaran bahasa, khususnya Bahasa Inggris, yang dilakukan dalam satu kali pertemuan (2x45 menit): relijius, jujur, disiplin, kerja keras, kreatif, mandiri, rasa ingin tahu, menghargai prestasi, bersahabat/komunikatif, gemar membaca, peduli lingkungan, peduli sosial dan tanggungjawab.
\end{abstract}

Kata Kunci: Pendidikan Karakter, Pembelajaran, Bahasa Inggris

\begin{abstract}
This article describes the application of character education in learning English. Character education is everything that the teacher does, which is able to influence the character of the learners. Teachers help create the character of learners. This includes examples of how the teacher behaves, the way the teacher talks or conveys the material, how the teacher has tolerant, and other related matters. Generally, main values of characters can be reflected when formulating indicators and developing teaching materials. Here are some integrating examples for each values of character on indicators and teaching materials in language learning, especially English, conducted in a single meeting (2x45 minutes): religiosity, honesty, discipline, hard work, creative, independence, curiosity, achievement orientation, friendly/communicative, fondness for reading, environmental care, social care and responsibility.
\end{abstract}

Keywords: Character Building, Learning, English

\section{PENDAHULUAN}

Pembentukan karakter merupakan salah satu tujuan pendidikan nasional. Pasal I UU Sisdiknas tahun 2003 menyatakan bahwa di antara tujuan pendidikan nasional adalah mengembangkan potensi peserta didik untuk memiliki kecerdasan, kepribadian, dan akhlak mulia. Amanah UU Sisdiknas tahun 2003 itu bermaksud agar pendidikan tidak hanya membentuk insan Indonesia yang cerdas, namun juga berkepribadian atau berkarakter, sehingga nantinya akan lahir generasi bangsa yang tumbuh berkembang dengan karakter yang bernafas nilai-nilai luhur bangsa serta agama.

Pendidikan karakter sangat diperlukan dalam membangun bangsa yang maju dan bermartabat. Negara ini tidak hanya perlu orang pintar secara 
keilmuan dari aspek intelektualitas $(\mathrm{Head})$, tetapi perlu juga kecerdasan hati (Heart) atau pengembangan perasaan nilai-nilai kemanusian dan memiliki keterampilan (Hand). Dengan kata lain Indonesia perlu manusia- manusia yang cerdas otaknya, lembut hatinya, dan terampil tangannya. Keberhasilan pembentukan karakter ada pada orang tua, guru, masyarakat dan pemerintah yang bisa bersinergis. Tanpa semuanya akan sulit tercapai keberhasilan pandidikan karakter.

Sebagaimana yang telah disebutkan bahwa guru juga turut andil besar dalam pembentukan pendidikan karakter. Oleh karena guru harus mampu hendaknya senantiasa menanamkan karakter pada anak didiknya dimulai dulu dari hal-hal sederhana dalam proses kegiatan belajar di kelas.

\section{METODE PELAKSANAAN}

Pada kegiatan pengabdian dalam bidang pendidikan ini, bentuk kegiatannya adalah sebagai berikut:

a. Melakukan rembug-pendapat dengan Kepala Sekolah SDN 106160 Desa Tanjung Rejo Kecamatan Percut Sei Tuan, untuk memilih khalayak sasaran.

b. Membuat Proposal.

c. Melaksanakan kegiatan pelatihan, dengan metode transfer ilmu dan praktek langsung.

Pada metode pelaksanaan penyuluhan dan pelatihan pendidikan karakter dalam pembelajaran Bahasa Inggris, terdapat beberapa tahapan:

a. Tahap pendahuluan. Dalam tahap ini kita mempersiapkan surat izin

dengan pihak terkait, mempersiapkan tempat pelatihan, mempersiapkan alat dan bahan.

b. Tahap sosilaisasi dan audiensi. Sosialisasi mengenai penyuluhan dan pelatihan ini dilakukan dengan cara mengumpulkan beberapa pihak terkait, mulai
Kepala Sekolah hingga guru-guru bidang studi dan staff pendidik sebagai peserta penyuluhan (pelatihan).

c. Tahap pelatihan. Berupa kegiatan pelatihan dan penyuluhan tentang pendidikan karakter dalam pembelajaan Bahasa Inggris; dimulai dari presentasi materi serta pelatihan bagaimana menuangkan nilai-nilai karakter dalam kegiatan belajar-mengajar Bahasa Inggris.

d. Tahap tanya-jawab. Dimana dalam bagian terakhir ini para serta diperkenankan untuk menanyakan segala hal terkait dengan materi yang disampaikan dan juga sumbang saran.

\section{HASIL}

Pendidikan karakter adalah suatu

sistem penanaman nilai-nilai karakter kepada warga sekolah yang meliputi komponen pengetahuan, kesadaran atau kemauan, dan tindakan untuk melaksanakan nilai-nilai tersebut. Pendidikan karakter dapat dimaknai sebagai "the deliberate use of all dimensions of school life to foster optimal character development" (Kemendiknas, 2012).

Dalam pendidikan karakter di sekolah, semua komponen (pemangku pendidikan) harus dilibatkan, termasuk komponen- komponen pendidikan itu sendiri, yaitu isi kurikulum, proses pembelajaran dan penilaian, penanganan atau pengelolaan mata pelajaran, pengelolaan sekolah, pelaksanaan aktivitas atau kegiatan kokurikuler, pemberdayaan sarana prasarana, pembiayaan, dan ethos kerja seluruh warga sekolah/lingkungan. Di samping itu, pendidikan karakter dimaknai sebagai suatu perilaku warga sekolah yang dalam menyelenggarakan pendidikan harus berkarakter.

Kertajaya (2010) mengatakan bahwa pendidikan karakter adalah ciri khas yang dimiliki oleh suatu benda atau 
individu. Ciri khas tersebut adalah asli dan mengakar pada kepribadian benda atau individe tersebut, serta merupakan "mesin" yang mendorong bagaimana seseorang bertindak, bersikap, berucap, dan merespon sesuatu.

Pendidikan karakter itu sendiri merupakan proses pembentukan karakter yang memberikan dampak positif terhadap perkembangan emosional, spiritualitas, dan kepribadian seseorang. Oleh sebab itu, pendidikan karakter atau pendidikan moral itu merupakan bagian penting dalam membangun jati diri sebuah bangsa.

Mulyasa (2011) menyatakan bahwa pendidikan karakter bertujuan untuk meningkatkan mutu proses dan hasil pendidikan yang mengarah pada pembentukan karakter dan akhlak mulia peserta didik secar utuh, terpadu, dan seimbangm sesuai dengan standar kompetensi lulusan pada setiap satuan pendidikan.

Pentingnya pendidikan karakter bermanfaat untuk menghasilkan pribadi yang tidak mengabaikan nilai sosial, seperti sopan, tanggung jawab, dan yang lainnya sehingga terciptalah pribadi yang berkarakter unggul. Lickona (1992) menyatakan bahwa ada tujuh alasan mengapa pendidikan karakter itu harus disampaikan:

a. Merupakan cara terbaik untuk menjamin anak-anak (siswa) memiliki kepribadian yang baik dalam kehidupannya;

b. Merupakan cara untuk meningkatkan prestasi akademik;

c. Sebagian siswa tidak dapat membentuk karakter yang kuat bagi dirinya di tempat lain;

d. Mempersiapkan siswa untuk menghormati pihak atau orang lain dan dapat hidup dalam masyarakat yang beragam;

e. Berangkat dari akar masalah yang berkaitan dengan problem moral- sosial, seperti ketidaksopanan, ketidakjujuran, kekerasan, pelanggaran kegiatan seksual, dan etos kerja (belajar) yang rendah;

f. Merupakan persiapan terbaik untuk menyongsong perilaku di tempat kerja; dan

g. Mengajarkan nilai-nilai budaya merupakan bagian dari kerja peradaban.

Sesuai dengan penjabaran UU No. 20 tahun 2003, Pedoman Pelaksanaan Pendidikan Karakter Kementerian Pendidikan Nasional Badan Penelitian menyebutkan terdapat beberapa nilai- nilai karaker:

a. Religious (religiosity). Sikap dan perilaku yang patuh dalam melaksanakan ajaran agama yang dianutnya, toleran terhadap pelaksanaan ibadah agama lain, serta hidup rukun dengan pemeluk agama lain.

b. Jujur (honesty). Perilaku yang didasarkan pada upaya menjadikan dirinya sebagai orang yang selalu dapat dipercaya dalam perkataan, tindakan, dan pekerjaan.

c. Toleransi (tolerance). Sikap dan tindakan yang menghargai perbedaan agama, suku, etnis, pendapat, sikap, dan tindakan orang lain yang berbeda dari dirinya.

d. Disiplin (discipline). Tindakan yang menunjukkan perilaku tertib dan patuh pada berbagai ketentuan dan peraturan

e. Kerja keras (hard work). Perilaku yang menunjukkan upaya sungguh-sungguh dalam mengatasi berbagai hambatan belajar, tugas, dan menyelesaikan tugas dengan sebaik-baiknya. 
f. Kreatif (creative). Berpikir dan melakukan sesuatu yang menghasilkan cara atau hasil baru berdasarkan sesuatu yang telah dimiliki.

g. Mandiri (independence). Sikap dan prilaku yang tidak mudah tergantung pada orang lain dalam menyelesaikan tugas-tugas.

h. Demokratis (democracy). Cara berpikir, bersikap, dan bertindak yang menilai sama hak dan kewajiban dirinya dan orang lain.

i. Rasa ingin tahu (curiosity). Sikap dan tindakan yang selalu berupaya untuk mengetahui lebih mendalam dan meluas dari sesuatu yang dipelajari, dilihat, dan didengar.

j. Semangat kebangsaan (sense of nationalism). Cara berpikir, bertindak, dan berwawasan yang menempatkan kepentingan bangsa dan negara di atas kepentingan diri dan kelompoknya.

k. Cinta tanah air (patriotism). Cara berpikir, bersikap, dan berbuat yang menunjukkan kesetiaan, kepedulian, dan penghargaan yang tinggi terhadap bahasa, lingkungan fisik, sosial, budaya, ekonomi, dan politik bangsa.

1. Menghargai prestasi (achievement orientation). Sikap dan tindakan yang mendorong dirinya untuk menghasilkan sesuatu yang berguna bagi masyarakat, mengakui, dan menghormati keberhasilan orang lain.

m. Komunikatif (communication).

Tindakan yang memperlihatkan rasa senang berbicara, bergaul, dan bekerja sama dengan orang lain.

n. Cinta damai (love of peace).
Sikap, perkataan, dan tindakan yang menyebabkan orang lain merasa senang dan aman atas kehadiran dirinya.

o. Gemar membaca (fondness for reading). Kebiasaan menyediakan waktu untuk membaca berbagai bacaan yang memberikan kebajikan bagi dirinya.

p. Peduli lingkungan (environmental care). Sikap dan tindakan yang selalu berupaya mencegah kerusakan lingkungan alam di sekitarnya dan mengembangkan upaya-upaya untuk memperbaiki kerusakan alam yang sudah terjadi

q. Peduli social (social care). Sikap dan tindakan yang selalu ingin memberi bantuan kepada orang lain dan masyarakat yang membutuhkan

\section{r. Tanggung jawab (responsibility).}

Menurut Elkind \& Sweet (2004), pendidikan karakter dimaknai sebagai berikut:

"Character education is the deliberate effort to help people understand, care about, and acts upon core ethical values. When we think about the kind of character we want for our children, it is clear that we want them to be able to judge what is right, care deeply about what is right, and then do what they believe to be right, even in the face of pressure from without and temptation from within".

Dari pernyataan diatas dikemukakan bahwasanya pendidikan karakter adalah upaya yang disengaja 
untuk membantu setiap orang untuk memahami, peduli, dan bertindak atas nilai-nilai etika. Ketika kita berpikir tentang nilai-nilai karakter yang kita ingin terapkan untuk anak-anak kita, jelaslah bahwa kita ingin mereka untuk bisa menilai apa yang benar, sangat peduli tentang apa yang benar, dan kemudian melakukan apa yang mereka yakini benar, bahkan dalam menghadapi tekanan dari luar dan godaan dari dalam.

Belajar bukan sekedar mengingat, tetapi juga mengembangkan kepekaan afektif. Berdasarkan hal tersebut, belajar bahasa adalah sebuah proses aktif, dinamis, dan berkesinambungan, yang tidak lagi menekankan aspek pengetahuan semata, tetapi juga menekankan aspek implementasi dan manfaat. Sebuah pembelajaran yang mengedepankan pendekatan komunikatif yaitu belajar menggunakan bahasa untuk berkomunikasi (Widdowson, 1987).

Cameron (2008) me nyatakan bahwa aktivitas belajar-mengajar bagi anak-anak haruslah kongruen artinya aktifitas-aktifitas itu disesuaikan dengan umur anak, pengalaman dan lingkungan sosiokultural mereka serta tingkat kebahasaan yang diajarkan haruslah mampu menjadi dasar bagi pe mbelajaran yang akan mereka hadapi pada jenjang pendidikan selanjutnya.

Untuk lebih jelasnya, secara umum, paparan nilai-nilai utama karakter selanjutnya dapat dicerminkan, antara lain pada saat memformulasikan indikator dan mengembangkan bahan ajar. Berikut ini adalah beberapa contoh pengintegrasian masing-masing nilai karakter pada indikator dan bahan ajar dalam pembelajaran bahasa, khususnya Bahasa Inggris.

\section{Tabel 1.1 Nilai Karakter dalam rencana Pelaksanaan Pembelajaran Bahasa Inggris}

\begin{tabular}{|c|c|c|}
\hline $\begin{array}{l}\text { Proses } \\
\text { Belajar }\end{array}$ & $\begin{array}{l}\text { Nilai } \\
\text { Karakter }\end{array}$ & Aplikasi \\
\hline \multirow[t]{4}{*}{$\begin{array}{l}\text { Pre- } \\
\text { Activity }\end{array}$} & $\begin{array}{l}\text { Relijius } \\
\text { (Sopan) }\end{array}$ & $\begin{array}{l}\text { - “Assalamu’alai } \\
\text { kum.” / } \\
\text { "Wa'alaikumsa } \\
\text { lam.” }\end{array}$ \\
\hline & $\begin{array}{l}\text { Peduli } \\
\text { (Sosial) }\end{array}$ & $\begin{array}{l}\text { "Hi! How are } \\
\text { you? How's } \\
\text { your feeling } \\
\text { today?" / Fine! } \\
\text { Good, Sir." } \\
\text { - "Is there } \\
\text { somebody } \\
\text { absent?" / Yes. } \\
\text { Mail is sick, } \\
\text { Sir". / "Well, } \\
\text { I'll recheck } \\
\text { you out (taking } \\
\text { attendance list) }\end{array}$ \\
\hline & $\begin{array}{l}\text { Peduli } \\
\text { Lingkungan }\end{array}$ & $\begin{array}{l}\text { - "Hhm... The } \\
\text { whiteboard } \\
\text { looks unclean." } \\
\text { - "Let me erase } \\
\text { them away, } \\
\text { Sir." }\end{array}$ \\
\hline & Komunikatif & $\begin{array}{l}\text { - "What chapter } \\
\text { (topic) should } \\
\text { we study } \\
\text { today?"/ } \\
\text { "Chapter 5, } \\
\text { Present Perfect } \\
\text { Tense, Sir." } \\
\text { - "Have you } \\
\text { finished your } \\
\text { homework? } \\
\text { Have you } \\
\text { studied our last } \\
\text { topic?" / Yes, } \\
\text { we have, Sir." }\end{array}$ \\
\hline \multirow[t]{3}{*}{$\begin{array}{l}\text { Whilst- } \\
\text { Activity }\end{array}$} & $\begin{array}{l}\text { Gemar } \\
\text { Membaca }\end{array}$ & 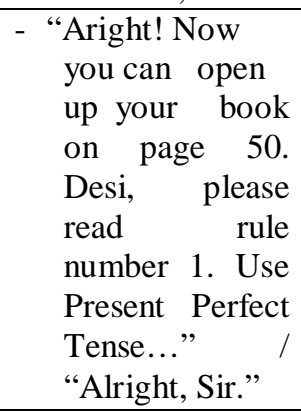 \\
\hline & $\begin{array}{l}\text { Berfikir } \\
\text { Logis, Kerja } \\
\text { Keras }\end{array}$ & $\begin{array}{l}\text { - "Do you know } \\
\text { what the } \\
\text { difference } \\
\text { between } \\
\text { Simple Past } \\
\text { Tense and } \\
\text { Present Perfect } \\
\text { Tense?" / "Yes, } \\
\text { Sir...." }\end{array}$ \\
\hline & Kerja Keras, & (Students are asked \\
\hline
\end{tabular}




\begin{tabular}{|c|c|c|}
\hline & $\begin{array}{l}\text { Mandiri, } \\
\text { Jujur, } \\
\text { Tanggung } \\
\text { Jawab }\end{array}$ & $\begin{array}{l}\text { to finish individual } \\
\text { work without } \\
\text { cheating) }\end{array}$ \\
\hline & $\begin{array}{l}\text { Rasa Ingin } \\
\text { Tahu, Jujur }\end{array}$ & $\begin{array}{l}\text { - "That's all. } \\
\text { Have you } \\
\text { understood? } \\
\text { Just ask if you } \\
\text { still don't get } \\
\text { it." / "Yes, Sir. } \\
\text { Would like to } \\
\text { give more } \\
\text { examples...?" } \\
\text {-'Sir, I have got } \\
\text { additional } \\
\text { reference. It is } \\
\text { said that will } \\
\text { can be used for } \\
\text { all subject, is } \\
\text { that true? So, } \\
\text { what about } \\
\text { shall?" / "Well, } \\
\text { I'm going to } \\
\text { explain..." }\end{array}$ \\
\hline & $\begin{array}{l}\text { Percaya Diri, } \\
\text { Disiplin }\end{array}$ & $\begin{array}{l}\text { - "Time is up! } \\
\text { Well. Who can } \\
\text { finish number } \\
\text { one? / "Yes. I } \\
\text { can, Sir" / } \\
\text { "Who's next?" }\end{array}$ \\
\hline & $\begin{array}{l}\text { Kreatif, } \\
\text { Kerja Keras }\end{array}$ & $\begin{array}{l}\text { - “Alright, guys. } \\
\text { It's very } \\
\text { common to } \\
\text { pour your } \\
\text { assignment on } \\
\text { paper. Next } \\
\text { week we will } \\
\text { practice how to } \\
\text { make Pop- } U p \\
\text { Book. You can } \\
\text { write } \\
\text { beautifully and } \\
\text { colorfully in } \\
\text { your Pop- } U p \\
\text { book. You will } \\
\text { work in a team. } \\
\text { So, every team } \\
\text { should help } \\
\text { each other. } \\
\text { Don't forget to } \\
\text { bring the } \\
\text { materials } \\
\text { (cartoon paper, } \\
\text { scissor, glue...) }\end{array}$ \\
\hline $\begin{array}{l}\text { Post- } \\
\text { Activity }\end{array}$ & $\begin{array}{l}\text { Kominikati, } \\
\text { Apresiatif }\end{array}$ & $\begin{array}{ll}\text { - } & \text { Well. Give } \\
& \text { applause to } \\
& \text { Syafril!! } \\
\text { - } & \text { Okay!! As I've } \\
& \text { promised I'll }\end{array}$ \\
\hline
\end{tabular}

\begin{tabular}{|c|c|}
\hline & $\begin{array}{l}\text { give a reward } \\
\text { for the three } \\
\text { best groups! } \\
\text { Here they } \\
\text { are... }\end{array}$ \\
\hline $\begin{array}{l}\text { Relijius, } \\
\text { Komunikatif, } \\
\text { Peduli }\end{array}$ & $\begin{array}{l}- \\
\text { "Okay!! I think } \\
\text { that's it all for } \\
\text { today. Don't } \\
\text { forget to study } \\
\text { and practice } \\
\text { again what } \\
\text { we've just } \\
\text { done at your } \\
\text { home. I'll see } \\
\text { you again next } \\
\text { week. Bye!" / } \\
\text { See you, Sir!" } \\
\text { - Assalamu'alai } \\
\text { kum.” / } \\
\text { "Wa'alaikumsa } \\
\text { lam.” }\end{array}$ \\
\hline
\end{tabular}

\section{KESIMPULAN}

Berdasarkan pembahasan diatas dapat disimpulkan bahwa pendidikan karakter ialah segala sesuatu yang dilakukan guru, yang mampu mempengaruhi karakter peserta didik. Guru membantu membentuk watak peserta didik. Hal ini mencakup keteladanan bagaimana perilaku guru, cara guru berbicara atau menyampaikan materi, bagaimana guru bertoleransi, dan berbagai hal terkait lainnya.

Belajar bukan sekedar mengingat, tetapi juga mengembangkan kepekaan afektif. Berdasarkan hal tersebut, belajar bahasa adalah sebuah proses aktif, dinamis, dan berkesinambungan, yang tidak lagi menekankan aspek pengetahuan semata, tetapi juga menekankan aspek implementasi dan manfaat.

\section{DAFTAR PUSTAKA}

Cameron, L. 2008. Teaching Languages to Young Learners. Cambridge: Cambridge University Press. Elkind, D.H. \& Sweet, F. 2004. You Are a Character Educator. Today's School.

Kemendiknas. 2012. Pembinaan Pendidikan Karakter di Sekolah Menengah Pertama. Jakarta. Kertajaya, H. 2010. Pendidikan 
Karakter. Jakarta: Gramedia

Lickona, T. 1992. Education for

Character: How Our School Can

Teach Respect and Responsibility. Bantam Books.

Mulyasa, H. E. (2011). Manajemen Pendidikan Katakter. Jakarta: Bumi Aksara. Undang-Undang Republik Indonesia No. 20 tentang Sistem Pendidikan Nasional. (2003). Jakarta: Ditjen Dikdasmen.

Widdowson, H.G. (1987). The Teaching of English as Communication, The Communicative Approach to Language Teaching”. Ed. C.J. Brumfit and K. Johnson. Oxford: Oxford University Press. 